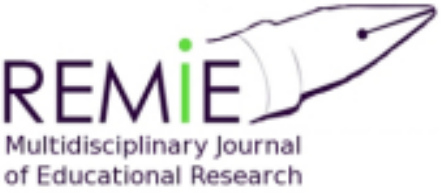

Multidisciplinary journal

of Educational Research

\section{Hipatia Press}

www.hipatiapress.com

Instructions for authors, subscriptions and further details:

http://remie.hipatiapress.com

\title{
Second Order of Sexual Harassment - SOSH
}

Ana Vidu ${ }^{1}$, Rosa Valls ${ }^{1}$, Lidia Puigvert ${ }^{1}$, Patricia Melgar ${ }^{2}$ \& Mar Joanpere ${ }^{1}$

1) University of Barcelona. Spain

2) University of Girona, Spain

Date of publication: February $15^{\text {th }}, 2017$

Edition period: February 2017-June 2017

To cite this article: Vidu, A., Valls, R., Puigvert, L., Melgar, P., \& Joanpere, M. (2017). Second Order of Sexual Harassment - SOSH. Multidisciplinary Journal of Educational Research, 7(1), 1-26. doi:10.17583/remie.2017.2505

To link this article: http://dx.doi.org/10.17583/remie.2017.2505

\section{PLEASE SCROLL DOWN FOR ARTICLE}

The terms and conditions of use are related to the Open Journal System and to Creative Commons Attribution License (CC-BY). 


\section{Second Order of Sexual Harassment - SOSH}

Ana Vidu

University of Barcelona

Lidia Puigvert

University of Barcelona

Mar Joanpere

University of Barcelona
Rosa Valls

University of Barcelona

Patricia Melgar

University of Girona

\section{Abstract}

Gender-based violence cannot be overcome without wide social support for the victims, which is dramatically limited by the violence against those who take an active stand in favor of survivors. The struggle against sexual violence requires simultaneous actions to protect both the direct victims of sexual harassment and the victims of second order sexual harassment - SOSH. Although SOSH was first defined in 1990 (Dziech \& Weiner, 1990) there has been a lack a research on the issue, despite its social and scientific importance. The objective of this article is two-fold: a) to provide a concept of SOSH that facilitates the present developments for science and society by identifying specific situations of persons and those with whom they work who have suffered from SOSH; and b) to disclose the main contributions under these situations from the perspective of several social frameworks including the legal system, university, citizenship, media and politics. Using a qualitative methodology, we conclude by highlighting the need to develop the joint actions of society as a whole to identify and legislate SOSH while empowering survivors and those who support them in an attempt to eradicate gender-based violence.

Keywords: Second Order of Sexual Harassment, gender-based violence, survivors 


\section{Acoso Sexual de Segundo Orden (SOSH)}

Ana Vidu

University of Barcelona

Lidia Puigvert

University of Barcelona

Mar Joanpere

University of Barcelona
Rosa Valls

University of Barcelona

Patricia Melgar

University of Girona

\section{Resumen}

La violencia de género no puede ser superada sin un amplio apoyo social a las víctimas, que está dramáticamente limitado por la violencia contra quienes toman una postura activa en favor de los sobrevivientes. La lucha contra la violencia de género requiere acciones para proteger tanto a las víctimas directas de acoso sexual como a las víctimas de acoso sexual de segundo orden -SOSH-. Aunque la primera definición de SOSH viene de 1990 (Dziech \& Weiner, 1990), ha habido una falta de investigación sobre el tema, a pesar de su importancia social y científica. El objetivo de este artículo es doble: a) proporcionar un concepto de SOSH útil para presentar los avances de la ciencia y la sociedad, a través de la identificación de situaciones específicas de las personas y aquellos con quienes trabajan y han sufrido SOSH; B) revelar las principales aportaciones para hacer frente a estas situaciones a través de diversos aspectos en los ámbitos jurídico, universitario, ciudadano, mediático y político. Utilizando una metodología cualitativa concluimos destacando la necesidad de desarrollar acciones conjuntas de toda la sociedad para identificar y legislar el SOSH, al tiempo que empoderar a los supervivientes y a quienes los apoyan, en un intento de erradicar la violencia de género.

Palabras clave: Acoso Sexual de Segundo Orden, violencia de género, supervivientes 


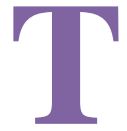

he World Health Organization (WHO, 2016) estimates that, at some point in their lives, $35 \%$ of women globally have suffered from physical and/or sexual violence, exercised either by their intimate partner or by a non-partner. Indeed, scientific studies show that up to $70 \%$ of women have experienced physical and/or sexual harassment by a romantic partner during their lifetime (United Nations, 2013). Furthermore, considering the gender violence that is suffered by young people in sporadic relationships (Shorey et al., 2012), the data are frightening. There is widespread agreement that this is a violation of human rights as well as a major scourge of society. To combat this enormous problem, the article raises the concept of Second Order Sexual Harassment - SOSH - because this pitfall cannot be overcome without social support for the victims.

We define SOSH as physical and/or psychological violence against persons who support victims of sexual harassment. Some people, groups and institutions that support survivors become subject to violence when they accompany them in the process of reporting or when they defend them from re-victimization as a form of coercion against such support. It is impossible to overcome gender violence without broad social support for the victims, which is dramatically limited by the violence against those who take an active stand in favor of survivors. The struggle against gender violence requires simultaneous actions to protect both the primary victims and the second order victims of sexual harassment. In addition to physical aggression, second order harassment includes reprisals, injuries, slander and the spreading of rumors, mobbing, bullying, stigmatization, isolation, discrimination in a person's professional or social lives, or stereotyping them, their families, their friends or their colleagues. This violence creates professional and psychological problems for the supporters, and it discourages others from standing with survivors and denouncing cases about which they may have knowledge.

The concept "SOSH" was first published with a similar conception as the one that is outlined in this article, in 1990 (Dziech \& Weiner, 1990), when second order sexual harassment began to be considered to be a key element in breaking the silence in the academic context. The lack of support for survivors leads them to feel unsafe in coming forward, and it produces a 'silencing effect' on the first order victims (Fisher, Cullen, \& 


\section{Vidu et al. - Second Order of Sexual Harassment}

Turner, 2000), especially when second order sexual harassment is not considered and properly approached. The international scientific community recognizes the importance and need for support and solidarity in all spheres of society (FRA, 2014).

Beginning with the contributions of the precursors of the concept (Dziech \& Weiner, 1990), second order sexual harassment was first introduced into public debate in the Spanish context. Considering that the Spanish environment is also influenced by this reality, the first workshop on the issue was held in Barcelona on December 19-20 ${ }^{\text {th }}, 2016^{1}$, and there were more than two hundred participants in attendance. With the aim of responding to the problem of $\mathrm{SOSH}$, the conference was focused on framing a conception that not only refers to the academic sphere but also considers the research that has been done on the issue over the last 25 years in Spain. The workshop created a context that facilitated a better understanding of whether the concept of SOSH was being socially known or used. In fact, at this first SOSH conference, most of the 24 speakers publicly explained that they had never heard of this approach before. However, they quickly began to identify many situations in which they or people who they knew had experienced the phenomenon. Indeed, their interventions (members of political parties, from the Media, NGOs, and participants from other social areas) proved to be relevant in breaking new ground on the path against sexual harassment in society as a whole.

The basis of the recognition of SOSH includes the documentary The Hunting Ground ${ }^{2}$ do and key contributions such as those of professor Ruth Milkman (2016) - a past president of the American Sociological Association and one of the first women who dared to break the silence in the United States higher education context by creating a women's movement to register a complaint against a university professor in the late 1970s. These essential inputs led science and society to locate the debate in the international context in which solidarity and networking are key elements. Additionally, they also provided examples of the movements' political impact in changing legislation and influencing society (End Rape on Campus, 2016) while they contributed to the transforming of a condition of passivity into bystander intervention (Banyard et al., 2005). 
Although SOSH was presented in the context of the analysis of gender violence in universities, it is also used and needs to be approached in many other contexts. Despite this fact, very little on the subject has thus far been researched and published. Thus, there is a clear gap in the research, which damages scientific knowledge in the area and leaves unexamined the serious social problem of violence against women. The reason why scientific contributions have not thus far been devoted to investigating the aspect of second order sexual harassment can be understood in multiple ways. Professor Ruth Milkman noted the importance of the concept "survivors first" (Choate, 2003), which refers to the significance of considering victims as being a priority in any process that is related to breaking the silence.

To place victims as a first concern, as we already have stated in the definition, it is important to be aware that victims need to feel empowered so that they may dare to move forward, and for that, they require the support of society. This support includes the defense of those who stand with the victims. Nevertheless, it is precisely the aim of identifying victims as a first concern (i.e., empowering survivors to report sexual harassment cases and protecting them thereafter) that it is necessary to guarantee that the people who defend them are also protected. Otherwise, victims will remain isolated, and they will not dare to progress in their cases in the context of the whole struggle of combating first and second order sexual harassment.

\section{State of the Art}

Gender-based violence is a reality that is becoming increasingly present in different areas of contemporary society (United Nations, 2013). Scholars are theorizing and describing situations from street harassment, academic and work harassment to sexual violence in many contexts (Padrós, 2014). Scientific research has been conducted on the issue, focusing not only on the causes of harassment but also on measures for its prevention and response (Gross, Winslett, Roberts \& Gohm, 2006). In this sense, mechanisms such as taking a stand in favor of victims, intervention and 
support have shown to be successful in breaking the silence (Reilly, Lott, Caldwell, \& DeLuca, 1992).

Once the silence is broken and the complaint process begins, victims must be strong, to feel empowered, not only to keep moving forward but also in facing possible retaliation and reprisal, which unfortunately may occur once their cases go public (Sable, Danis, Mauzy, \& Gallagher, 2006). As many victims have asserted (Clark \& Pino, 2016) peer-support constitutes the most successful mechanism in such situations. Therefore, protecting the victims' support is as important as protecting the victims themselves.

In this regard, several steps have been taken during the last decade. The European (Official Journal of the European Union, 2012) has developed standards on the rights, support and protection of victims of crime, including women victims of gender-based violence and their children. These measures include specific mechanisms of protection, including instances of secondary and repeat victimization or retaliation.

Under this framework, the second order of sexual harassment also must be addressed. SOSH occurs in different societal contexts. It may affect anyone, of any age, in any environment. The primary goal in these contexts is to support and take a clear stand in favor of the victim of any situation of sexual harassment.

While SOSH may take place in many different contexts, the university embodies one of these spaces. From the very first research, specifically on gender-based violence within universities that was carried out in the late 1950s in the United States (Kirkpatrick \& Kanin, 1957), many studies, surveys and investigations have been performed that aim to face and solve this problem. The 1970s are considered to be a key decade for this issue. The percentage of students who claimed to have experienced undesirable sexual advances at their universities was around 30\% (Benson \& Thomson, 1982). The Title IX legislation ${ }^{3}$ together with the first public reports at US universities as well as the first student mobilizations and complaints against university professors for sexual harassment contributed to breaking ground for a new wave of protests and actions to overcome sexual violence in academic contexts. However, while significant steps have already been achieved since then, especially in the US, much more work needs to be 
done at a deeper level, protecting not only survivors but also those who risk themselves to protect them, those who are considered to be the second order victims of sexual harassment (Clark \& Walker, 2011).

Faced with this reality, several researchers have analyzed the mechanisms of prevention and the campaigns that have been carried out at different universities. For instance, after evaluating the impact of the results of several university measures and mechanisms that have addressed sexual harassment, Coker and colleagues (2016) highlighted that the programs that are based on the bystander intervention, such as the Green $D_{o t}{ }^{4}$ (Banyard et al., 2005), are the most successful, especially because they include the bystander training that is required by the Campus SaVE Act (Sexual Violence Elimination ${ }^{5}$ ).

The powerful meaning of bystander intervention stresses the importance of empowering "bystanders." According to scientific contributions that have shed light on the key role of the Friends of survivors (Banyard et al., 2010), one in three women in college and one in five men have friends who have been told that they were victims of an unwanted sexual experience during their college years. If they do not feel empowered, they will likely not support the victims they may know, which limits the potential for bystander intervention to occur.

The issue of gender violence in universities has also begun to receive attention at the European level. Oliver (2011) analyzed the impact of gender violence in United Kingdom universities. The author emphasizes the negative impact of suffering gender violence in the personal and professional lives of these survivors. Along these same lines, Corradi and Stöckl (2016) recently published the results of a cross-national analysis that evaluated the role of the state, the social movements and the adminsitrative bodies in the struggle against gender violence in 10 European countries, and they concluded that social movements and supra-national bodies may be able to challenge state power on this issue.

The first research project that analyzed gender violence within the Spanish academic context found that $62 \%$ of the students were aware of or had suffered from specific situations of gender violence at their universities. Indeed, the research shows that $98 \%$ of the respondents did not know where to go to report the facts of their cases (Valls, Puigvert, 
Melgar, \& García-Yeste, 2016). This research has been crucial in breaking the silence about this problem.

In the Spanish context, different important initiatives have emerged since then. Considering the need for peer-support identified by the research, student protests and the activism that has been taken up to overcome this problem, a peer-to-peer support network was created in Spain for the first time in 2013: the Solidarity Network of Victims of Gender Violence at Universities ${ }^{6}$. Additionally, beyond the university context, where the concept was first raised, steps have also been taken in other contexts to better approach not only victims but also victims' supporters. For instance, the campaign organized by "Jueces por la Democracia" [Judges for Democracy $]^{7}$ in Spain constitutes an example of this type of action beyond the institutional framework, and it is focused on a proposal for legislative protection to the complainants and witnesses of corruption. "Jueces por la Democracia" seeks specific legislations to protect both the victim complainants and the witnesses against any type of harassment, defamation or slander, or any process that may lead the complainant and the complaint into situations such as stigmatization, isolation, economic uncertainty or other damaging psychological effects.

\section{Methodology}

With the objective of developing a concept of $\mathrm{SOSH}$ as well as describing the implications that this type of harassment has for the people who suffer because of it, this study has been carried out using a qualitative methodology of research (Denzin \& Lincoln, 2005). The analysis was conducted using a narratives approach (Davis, 2002). Through the analysis of the subjects' narratives, this approach enables the researcher to obtain a deeper and better understanding of the complexity of the human experience. Additionally, it emphasizes the importance of employing concrete examples of real facts, thus building a space of confidence in which the story becomes the channel for the creation of awareness of the concrete reality, in this case, the consequences of SOSH. 
REMIE-Multidisciplinary Journal of Educational Research, 7(1) 9

\section{Study Design}

The data were gathered through an in-depth documentary analysis and interviews.

\section{Documentary Analysis}

The documentary analysis aimed to identify actions, mechanisms, legislation, research projects and other types of research documents and published materials at the Spanish and international levels on the topic of the prevention and response of gender-based violence, the protection of survivors as well as measures to address situations of first and second order harassment. We identified a gap in the existence of these types of materials on the specific topic of SOSH, which has been approached to a limited extent in research projects in the US but not in other domains.

\section{Interviews}

Qualitative interviews (nine) were carried out with the goal of obtaining a better understanding of how SOSH is identified by interviewees who have found themselves - or the people with whom they work - in these types of situations, as well as gathering qualitative data that enable us to advance in a proper conceptualization of this reality.

Accordingly, the following criteria were established to select the study participants: (1) subjects who have suffered second order sexual harassment, and (2) subjects who either know someone or work with someone who has suffered because of it.

Given the sensitivity of the topic of study, the research participants responded freely to the questions that they considered to be adequate; it was assumed that some of the questions would not be answered.

All of the names and personal information have been carefully treated and only used for the purpose of this article, according to the agreement that was established by both parties, the researcher and the interviewed 
10 Vidu et al. - Second Order of Sexual Harassment

subjects. In addition, all real names have been anonymized and fictitious names have been created.

Table 1.

Interviews profiles

\begin{tabular}{llll} 
Interview & Gender & Age (years old) & Profession \\
\hline E1. Maria & Female & 25 & Professor \& Researcher \\
E2. Peter & Man & 41 & University professor \\
E3. Mery & Female & 27 & Postdoctoral researcher \\
E4. Blanca & Female & 51 & University professor \\
E5. & Female & 46 & Professor \& Researcher \\
Bibiana & & & \\
E6. Claire & Female & 50 & University professor \\
E7. & Female & 27 & Researcher \\
Roberta & & & \\
E8. Tom & Man & 48 & University professor \\
E9. Judith & Female & 64 & Economics \& Women \\
& & & activist
\end{tabular}

\section{Data Analysis}

The data were interpreted and analyzed according to pre-established categories that were defined in relation to the aims of the study: on the one hand, to provide a concept of SOSH, and on the other hand, to disclose contributions to facilitate a better understanding and response of these types of situations. On this basis, the data related to situations of $\mathrm{SOSH}$ were first identified and analyzed. Second, information was analyzed with the aim of identifying actions that should be adopted to empower victims, their supporters - including peer-support - and all of the brave people who take a stand with them. In turn, this later information was categorized considering five social dimensions: legal, university, citizenship, media and 
political. These categories have been recognized as the social spheres in which $\mathrm{SOSH}$ is more likely to occur.

\section{Results}

The results of this study are structured in two sections: 1) the situations of $\mathrm{SOSH}$; and 2) contributions and proposals.

\section{Situations of SOSH}

(...) to get to name things that have always happened, but never before have had a definition, neither have been considered a fault. Thus, that behavior that was taking for granted until the moment, it is now called second order sexual harassment, and even more important, it is having great impact on society, since the indifference with which some people could feel 'outside the problem' disappears. Including this concept in the everyday language and also in different actions at different levels, it makes people aware of the fact that, if they are not intervening, they are letting the problem happen. (E7, Roberta)

The situations of SOSH can happen anywhere: in the street, at the university, in the political or judicial sphere, in the media or in any other social spaces. Many people acknowledge that they have experienced SOSH, but they have never identified it as such. Within the scientific community, there is consensus on the key importance of recognizing situations of $\mathrm{SOSH}$ as a first step in determining the potential circumstances in which SOSH occurs and thus being able to intervene. Therefore, in this section, we focus on identifying such situations that have occurred in some of these various spaces. A special emphasis is placed on describing and approaching SOSH from the university perspective. This is because the university space is a sphere in which situations of sexual harassment and second order harassment were initially studied.

Taking a stand in favor of the victims and deciding to intervene is also the context in which reprisals and retaliations are experienced (Dey, Korn, \& Sax, 1996). One example is described by Roberta, a researcher who has suffered retaliations because she publicly positioned and chose to fight 


\title{
12 Vidu et al. - Second Order of Sexual Harassment
}

against gender violence. As she explains, the retaliations and criticisms that she has experienced have been not only in relation to her academic and professional career, but they have also occurred on a personal level:

\begin{abstract}
(...) the hardest attacks of the entire period of my involvement in this struggle came precisely for this very reason, for supporting survivors... and there were comments, criticism and attacks like: 'you are not doing the work well anymore'; 'your thesis is no well done and you have to assume it'; 'your relationship with the people who support you is suspicious'; 'I wonder what she has done to get support', ...disseminating doubts on my most intimate personal relationships. (E7, Roberta)
\end{abstract}

Student' movements have also been mobilized against an alleged harasser professor who, after having been suspended from his teaching after being reported by a student for misconduct, wanted to return to his position. As an opposition to this, student mobilizations and a peer-to-peer solidarity network decided to organize a signature campaign that led to negative comments. Maria describes this situation:

The strongest case was last June when we were in the middle of a campaign to achieve the non-reintegration at the university of one of the harassers, at the most intense moment of the campaign, when students had already achieved more than 1000 signatures against him, and so, we had the opportunity to raise a unanimous NO in front of their defenders. Some media, with the complicity of some university members, decided to expose false information about the research group [that has for long now fought against gender violence]. (E1, Maria)

The situations of SOSH may also take place for people who in their quotidian lives face comments and attacks, even in leisure spaces with friends or family. This university professor also describes specific situations and consequences for those who work day-to-day in the struggle to make universities free of sexual harassment. 


\section{REMIE-Multidisciplinary Journal of Educational Research, 7(1) 13}

(...) there have been varied consequences and of different gravity: nervousness, anxiety, somatizations, sleep disorder, obstruction of the academic progression... especially for those who are in precarious employment situations... (E8, Tom)

Holding positions of responsibility at different levels and spaces can be a channel to contribute to the breaking of silence, or on the contrary, it can help to impede such progress, especially in cases in which the defended interests are not the same as those of the victims. Nevertheless, when a stand is taken on the victim's side, situations of SOSH may take place, for instance, in line with reprisals for holding positions of responsibility in committees for equality or for researching issues that are related to sexual violence in universities.

Everything happened because of my support to the students' complaint. It ended with my resignation... [of university position] once realizing that nobody, absolutely nobody, supported me. The outcomes turned out to be total isolation and solitude. Not being cooperative, as I was told to be, has consequences. Anyway, beyond the explicit rejection that one can perceive in these situations, there is another lighter rejection, less thick but it also reinforces that isolation; I am referring to the people who like you and you know it, but who are out there, because they prefer not to be identified with you. They do not want too much contact and they do not operate beyond saying "goodbye" in the hallway. Two and a half years have already passed and I got used to this solitude... (E4, Blanca)

In the following quote, this professor describes the negative consequences for her collaboration in a university investigation against sexual harassment. A campaign of professional discredit was waged against her together with a lack of action by the institution; the response was the opposite of a lack of action: she was removed from her position.

Tom, a university professor, explains situations that have been suffered by other people of whom he is aware because they supported direct victims of sexual harassment. 


\section{Vidu et al. - Second Order of Sexual Harassment}

I work in the university context as a professor. I know colleagues who have been the subject of slanders and direct attacks for supporting victims of sexual harassment in the university context. These attacks, and the negative consequences derived from them, have occurred both in the phases of the complaint by the victims of sexual harassment and in the subsequent phase once the harassment previously reported has been verified... attacks ...: defamations, rumors, obstructing the academic career of the person, defamatory public campaigns, attacks against the honor of the person... (E8, Tom)

Other situations of second order sexual harassment can be experienced in different spaces at any moment. The street has been and still is a place where violence and harassment may still be perpetuated. Thus, SOSH may be leveled against those who decide to support a victim in the form of daily street harassment.

It can be observed that people who risk taking a position in favor of victims by supporting them face consequences that can be brought about by those who are supposed to protecting them or by those who seek to discredit them by creating an environment of doubt towards them or towards their work. The example that is provided by Maria sheds lights on this type of situation:

(...) once, having a drink with my friends in a bar, suddenly a boy appeared. Many of us did not know anything about him, but he sat and spent time with as at the table monopolizing the conversation and reproducing all the attacks which have appeared somewhere or comments he heard. So, he totally interrupted the conversation that we were having trying to spread an environment of doubt regarding my person, my work. (E1, Maria)

The above example demonstrates how situations of SOSH might take place in those spaces where silence is still a part of the everyday reality. However, this not only happens at work but also in the family context. In Peter's narrative, this is well emphasized:

(...) it has to be emphasized that this is happening, especially in the immediate surroundings. In the family and friends' context, there are very obvious cases of this type of second order harassment; in the 


\section{REMIE -Multidisciplinary Journal of Educational Research, 7(1) 15}

spaces where the silence prevails about the most aggressive and sad situations of harassment. (E2, Peter)

Peter's narrative also reveals how he suffered SOSH because he helped a relative who was sexually abused. Families must confront difficulties and adverse consequences for supporting their children and siblings.

Peter's narrative also reveals how he suffered SOSH because he helped a relative who was sexually abused. Families must confront difficulties and adverse consequences for supporting their children and siblings. (E2, Peter)

SOSH also affects social organizations that are aimed at the struggle against gender violence and are deeply committed to reporting and protecting survivors. Judith, who has been involved in a feminist organization for many years, explains: "At the concentrations, groups of men and women appeared to insult us for defending women's rights within the existing laws". (E9, Judith)

This last November at a workshop, one of our colleagues publicly received insults such as "you do not know enough" and "you are lying" because of raising the issue of the shortcomings of the judicial system and the local police, in particular when they care for women who go through the processes of violence. (E9, Judith)

We can also focus on the consequences of a Mexican group of women called Las Morras ${ }^{8}$. They began to receive death threats and constant attacks due to their public involvement in the increasing situations of gender violence. However, far from stopping them, these attacks led them to become better organized as a group, and they are currently carrying out periodic collective actions; even as the attacks continue, they struggle for the rights of Mexican women.

\section{Contributions and Proposals}

In this section, we explain our contributions and proposals according to our analysis, drawing on the documentary research and taking into account the 


\section{Vidu et al. - Second Order of Sexual Harassment}

interviewees' narratives, which are considered to be highly relevant in empowering victims, their supporters, and all those who take a stand with them. These are the actions and strategies that can be implemented from manifold perspectives.

Legal perspective. The response from the legal perspective comes through the recognition of SOSH at the legal level.

One of the main legal elements focuses on the consideration of second order sexual harassment as a part of the legislation on gender violence. In other words, this measure pretends to broaden the concept of the victim; thus, it contemplates not only first order victims but also victims of second order sexual harassment. This legal coverage is necessary to create mechanisms of prevention and protection for both first and second order victims.

In this regard, it is of primary importance to overcome the barriers within the legal system; also central are the experts who work on protecting survivors of sexual violence. The recognition of the SOSH at the legal level, in order to successfully approach the first order harassment, was broadly defended. Those who provide testimony are often afraid to become involved, depending on the type of case, due to the reprisals that they might suffer. Feminist professionals who support survivors have at times been discredited. Additionally, the lawyers who represent survivors may be victims of SOSH. Indeed, bystanders who declare that they are in favor of a victim do not always feel protected in taking that position.

SOSH must be approached from a collective perspective as it affects those who stand in favor of the victim. In this sense, one of the actions that has been claimed by victims is the creation of tools for protection in the form of judiciary power. A specific action that was suggested was the approval of a law project that would include victims' protection in cases of direct and second order harassment and establishment of consequences within social power relations for doing such transgressions.

University perspective. Universities also must address this issue. As has been already stated, commissions for equality and other institutional mechanisms that are created by the university should be developed in 
collaboration with students and other collectives, especially those that have arisen from below, to tackle first and second order harassment and to protect and give support to cases that are considered to be SOSH. Thus, it is crucial to assist second order victims in the same way that survivors of direct gender violence are assisted.

Unlike the general perception, those who dare to file a sexual harassment complaint do not do so as an attack on universities; rather, they take such action as a means of contributing to making them safer, violencefree spaces. This indeed becomes a way of publicly defending such institutions, and it is a step toward making such institutions more democratic and transparent. The existence of students who report cases of sexual harassment together with the institutional mechanisms that are already being implemented in higher education centers are two essential elements for getting over sexual harassment. As has been observed in the literature, peer-support is the most efficient mechanism to help survivors face and overcome what has occurred to them. Acknowledging this, it is also important to recognize students and their activism, especially considering that their aim is to ask for institutional support for the victims. Survivors should not have to feel alone once they decide to report any type of sexual harassment in their context. To avoid this, spaces of solidarity and support should be created that seek to prevent these types of situations from occurring as well as to encourage supporters' interventions to the extent that the victims want.

The above findings make it clear that the people who fight against second order sexual harassment are truly revolutionary, as they are contributing to a better society. There is a need to build universities and societies that are deeply engaged with all survivors and for the establishment of strongly committed committees for equality that are led by highly trained people. University administrations must take a position against any situation of sexual harassment. As in any other space, within the university, those who do not take a clear stand on the victims' side are through their inaction perpetuating SOSH.

Citizenship perspective. Mainstream society also needs to be aware of the importance of supporting victims and the brave people who dare to take 


\section{Vidu et al. - Second Order of Sexual Harassment}

a positive stand with the victims of first and second order sexual harassment and enhancing networks of solidarity among them to prevent $\mathrm{SOSH}$ from occurring. Social movements and civic organizations, each working from its own perspective, should take a clear position and protect those who have already been positioned in this struggle. This is central in the promotion of peer networks and in encouraging people to speak up about incidents and cases of sexual harassment. Community actions are essential to approach these realities and to learn the truth, especially regarding sexual harassment, which usually involves sensitive issues that are difficult to face.

Another idea that is considered to be of high relevance in fostering the public debate on SOSH is the strengthening and promotion of organizations that are already working to prevent gender violence, specifically, women's associations that are working to overcome gender violence and sexual harassment and feminist platforms. In this regard, public institutions that are a part of the larger public organism, which are already taking action to combat sexual harassment within their own institutions, criticize the positions that are often taken in favor of the aggressor, even when such positions are taken on behalf of those institutions. All actions that are taken in support of the victims of sexual harassment should be backed.

It is thus important to recognize the need for more dialogue and solidarity, creating optimal contexts for raising awareness and promoting the mechanisms for preventing harassment. Another aspect that has been observed is the emphasis that is placed on the importance of protecting the victims of SOSH within the educational community (e.g., primary and secondary school). As in the university, those who defend children who are bullied based on sexual orientation in primary and secondary school must be protected and recognized for their courage. The defense of the 'take a stand!' position against the aggressor has yet to be completely assumed by the educational community as an institution; such dynamics occur within this sphere as they do within the others. Protecting the victim is a matter of bravery. Thus, the aim is to reinforce the importance of positioning themselves, as well as the institutions, for instance, alongside children who are bullied on sexual issues, which at times requires the criticizing of 


\section{REMIE -Multidisciplinary Journal of Educational Research, 7(1) 19}

positions that are in favor of the aggressors. Not taking a stand reinforces the harassment and allows the situation to be perpetuated.

Media perspective. The Media also plays an important role in breaking the silence. In this sense, the data analyzed reveal the image of the victims of gender violence that the Media has portrayed, as the Media often blames such situations on the victims. Acknowledging how harmful this is, the key point is to ask the Media to present rigorous material, to use accurate language and to promote the visibility of women.

Defamation and not taking a stand through the Media also constitutes a way of perpetuating SOSH. Responsibility should also be taken in this sphere. In this sense, a proposal that is drawn from the analysis of the creation of regulations aimed at making a more responsible and sensitive Media in relation to the information that they provide and all content that is related to gender violence and sexual harassment that is displayed should thus be carefully designed to protect victims of first and second order harassment, for example, by broadly including gender as part of a positive journalistic practice. In addition, with regard to citizen involvement, they can create mechanisms that pressure the Media to engage in the struggle against sexual violence. In this regard, sexual violence can be presented as an issue of public concern. Survivors and activists seek to change the perception of sexual harassment from being a state secret and reframe it as a social problem that should be addressed at the mainstream level.

In the same vein, it is important to bear in mind the specific consequences - for victims and for women in general - that may provoke the display of any type of information. Thus, all journalists should be aware of this. Taking this into account, the development of a specific and rigorous protocol that guides journalists to treat the information related to sexual harassment cases (or related aspects) could be of significant help in avoiding harmful practices and protecting all types of victims. As is widely known, TV programs, such as TV series, televised sports and social networks, can be seen as naturalizing violence against women. In this regard, the Media should be rigorous, contrasting the information that they obtain and working to attain true gender parity. Finally, the Media should be aware that any single intervention that is done in a case of sexual 
harassment in a public platform does have an impact. Thus, care should be taken not to aggravate the suffering that $\mathrm{SOSH}$ victims already endure.

Political perspective. What could be of benefit would be a consensus on the idea that SOSH constitutes an important issue that needs to be addressed by the entire community on a collective basis as well as from the institutional side. Joint actions are needed in this regard to lead to an agreement among the different political parties in the treatment of this social problem.

The analysis of the data was conducted from the political perspective and demonstrates the importance of transforming the findings of this research on primary and SOSH into political resolutions, for instance, by articulating an immediate rejection of first and second order sexual harassment through actions such as implementing concrete measures against the potential aggressors.

Another aspect that is observed within this realm is the importance of advancing towards the approval of concrete actions and laws that express support to victims as well as creating a mechanism for providing youth education and training all professionals who work in public services and institutions (e.g., police, teachers) on the topic of sexual harassment.

\section{Conclusions}

The violence suffered by people who take an active stand in favor of victims may limit their actions if their position is not socially supported. Through this qualitative study, which unveils the narratives of $\mathrm{SOSH}$ victims and analyzes diverse perspectives in approaching it in different spheres, this article sheds light on the existence of the reality of second order sexual harassment, which goes beyond the sexual harassment of the original victims. Naming such types of behavior is crucial in the generation of mechanisms of protection towards those who choose to stay in solidarity with first order victims and help them in their struggle.

Through this study, we elaborated, on the one hand, a definition of the concept of SOSH, which is thus far little known in the sexual harassment literature, and on the other hand, we drew different insights and proposals 


\section{REMIE -Multidisciplinary Journal of Educational Research, 7(1) 21}

from different social areas, emphasizing the legal, university, citizenship, media and political perspectives. Through these contributions, the present article aims to raise awareness among citizens of a deep and invisible problem, so that the different social sectors can develop actions and thus contribute to the prevention and response to gender-based violence in our society.

The commitment to provide mechanisms based on scientific and social contributions that have been shown to be successful in combating both first and second order sexual harassment has revealed some key principles: empowering friendship, promoting peer-support and solidarity actions. These important concepts help victims to feel empowered to denounce and reject the violence that they suffered, and they encourage the society as a whole to support the victims and to reject those who perpetuate violence. In this way, the crimes that continue to be perpetrated to this day, as described in the following narratives, can be reversed.

It is very necessary to empower all citizens to be able to simultaneously tackle the roots of the first and second order attacks. This second order harassment represses many actions from supporting the victims, and this fact makes it difficult for survivors to feel protected and to be brave enough to respond to any assault. (E2)

(...) it is crucial to create mechanisms of collective and institutional reaction facing the harassment. Otherwise, collective and institutional responsibility is not being addressed. In those cases of sexual harassment in which harassment is tolerated, we observe lack of collective and institutional responsibility. (E8)

The results that are presented in this paper show that solidarity between and towards persons who support victims is crucial in the struggle against first and second order sexual harassment. Starting from the question of: 'who are the people who stand in solidarity with others?' as stated by the authors of The Hunting Ground (Dick \& Ziering, 2016), we find both women and men. Indeed, we find both women and men supporting victims, as well as women and men who fail to offer support or who lapse into conspiratorial silence. Society must overcome and reject any false stereotype regarding both situations. At any time in history, there have 
been women who have defended others and who have stood with survivors, as well as others who worked against them or who did not take any action. Furthermore, not all men are perpetrators; there are many men who reject such behavior and who defend victims; and some of them suffer because they have done so. As someone stated, "if you are not part of the solution, you are part of the problem." The struggle against the personal cost of standing up against sexual harassment in academia is still a challenge that must be socially addressed.

\section{Acknowledgment}

We would like to acknowledge those brave direct and second order victims in their struggle for societies to become free of gender violence, standing always on the victim's side, despite coming under attack for doing so.

\section{Notes}

${ }^{1}$ For more information, see: http://crea.ub.edu/2ordervictims/

${ }^{2}$ The Hunting Ground documentary, directed by Kirby Dick and Amy Ziering, was released in 2015 in the United States and shows the reality of sexual harassment at several college campuses in the United States. The documentary is focused on students' cases, showing not only their own stories but also their mobilization and the networks that they created to make institutions responsible for the sexual violence that occurs at their universities and thus raise awareness about a public issue that needs to be approached by society as a whole.

${ }^{3}$ For more information, see: https://www.dol.gov/oasam/regs/statutes/titleix.htm

${ }^{4}$ For more information, see: http:www.livethegreendot.com

${ }^{5}$ For more information, see: http://thecampussaveact.com/

${ }^{6}$ For more information, see: https://www.facebook.com/Red-solidaria-dev\% $\mathrm{C} 3 \%$ ADctimas-de-violencia-de-g\% $3 \%$ A9nero-en-las-universidades$834367176577567 /$

${ }^{7}$ For more information, see: http://juecesparalademocracia.blogspot.com.es/

${ }^{8}$ For more information, see: https://www.facebook.com/pg/morrascontacto/likes/

\section{References}

Banyard, V. L., Plante, E. G., Cohn, E. S., Moorhead, C., Ward, S., \& Walsh, W. (2005). Revisiting unwanted sexual experiences on campus: a 12-year follow-up. Violence Against Women, 11(4), 42646, doi: 10.1177/1077801204274388 
Banyard, V. L., Moynihan, M. M., Walsh, W. A., Cohn, E. S., \& Ward, S. (2010). Friends of survivors: the community impact of unwanted sexual experiences. Journal of Interpersonal Violence, 25(2), 24256. doi: 10.1177/0886260509334407

Benson, D. J., \& Thomson, G. E. (1982). Sexual Harassment on a University Campus: the confluence of authority relations, sexual interest and gender stratification. Social Problems, 29(3), 236-251, doi: $10.2307 / 800157$

Choate, L. H. (2003). Sexual assault prevention programs for college men: An exploratory evaluation of the men against violence model. Journal of College Counseling, 6, 166-176, doi: 10.1002/j.21611882.2003.tb00237.x/abstract

Clark, A., \& Pino, A. (2016). We Believe You. Survivors of Campus Sexual Assault Speak Out. New York: Holt Paperback.

Clark, J. J., \& Walker, R. (2011). Research Ethics in Victimization Studies: Widening the Lens. Violence against Women, 17(12), 1489-1508, doi: 10.1177/1077801211436167

Coker, A., Bush, H. M., Fisher, B., Swan, S. C., Williams, C. M., Clear, M. R., \& DeGue, S. (2016). Multi-College Bystander Intervention. Evaluation for Violence Prevention. American Journal of Preventive Medicine, 50(3), 295-302. doi: 10.1016/j.amepre.2015.08.034 Corradi, C., \& Stöckl, H. (2016). The lessons of history: The role of the nation-states and the EU in fighting violence against women in 10 European countries. Current Sociology, 64(4), 671-688. doi: $10.1177 / 0011392116640457$

Davis, J. (2002). Narrative and Social Movements. In J.E. Davis (Ed.), Stories of Change: Narrative and Social Movements (pp. 3-29). Albany NY: State University of New York Press.

Denzin, N., \& Lincoln, Y. (2005). The SAGE Handbook of Qualitative Research (4th Editio). Sage Publications.

Dey, E. L., Korn, J. S., \& Sax, L. J. (1996). Betrayed by the Academy: The Sexual Harassment of Women College Faculty. Journal of Higher Education, 67(2), 149-173. Retrieved from http://www.tandfonline.com/action/showCitFormats?doi=10.1080\% 2F00221546.1996.11780254 
Dick, K., \& Ziering, A. (2016). The Hunting Ground. New York: Skyhorse Publishing.

Dziech, B.W., \& Weiner, L. (1990). The Lecherous Professor: Sexual Harassment on Campus. Chicago: University of Illinois Press.

End Rape on Campus (EROC) (2016). Annual Report, April 2015-April 2016. Retrieved from http://endrapeoncampus.org/erocannualreport

Fisher, B. S., Cullen, F. T., \& Turner, M. (2000). The sexual victimization of college women (NCJ 182369). Washington, DC. Retrieved from https://www.ncjrs.gov/pdffiles1/nij/182369.pdf

FRA. (2014). Violence against women: an EU-wide survey. Main results report. European Union Agency for Fundamental Rights.

Luxembourg: Publications Office of the European Union. Retrieved from http://fra.europa.eu/sites/default/files/fra-2014-vaw-survey-ata-glance-oct14_en.pdf

Gross, A. M., Winslett, A., Roberts, M., \& Gohm, C. L. (2006). An Examination of Sexual Violence Against College Women. Violence Against Women, 12(3), 288-300. doi: 10.1177/1077801205277358

Kirkpatrick, C., \& Kanin, E. (1957). Male Sex Aggression on a University Campus. American Sociological Review, 22(1), 52-58. Retrieved from http://www.jstor.org/stable/2088765

Milkman, R. (2016). A New Political Generation: Millennials and the Post2008 Wave of Protest. 2016 Presidential Address. American Sociological Review, 1-31, doi: 10.1177/0003122416681031

Official Journal of the European Union. (2012). Directive 2012/29/EU of the European Parliament and of the Council of 25 October 2012 establishing minimum standards on the rights, support and protection of victims of crime, and replacing Council Framework Decision 2001/220/JHA. Volume 55. 12 November 2012. L315. Legistation. English edition. Retrieved from http://eurlex.europa.eu/legal-content/EN/TXT/?uri=OJ:L:2012:315:TOC

Oliver, E. (2011). Women's. In S. Jackson, I. Malcolm, \& K. Thomas (Eds.), Gendered Choices. Learning, Work, Identities in Lifelong Learning (pp. 69-83). London, UK: Springer.

Padrós, M. (2014). A Transformative Approach to Prevent Peer Violence in Schools Contributions from Communicative Research Methods. 
REMIE-Multidisciplinary Journal of Educational Research, 7(1) 25

Qualitative Inquiry, 20(7), 916-922. doi:

10.1177/1077800414537217

Reilly, M. E., Lott, B., Caldwell, D., \& DeLuca, L. (1992). Tolerance for

Sexual Harassment Related to Self-Reported Sexual Victimization.

Gender and Society, 6(1), 122-138. doi:

$10.1177 / 089124392006001008$

Sable, M. R., Danis, F., Mauzy, D. L., \& Gallagher, S. K. (2006). Barriers to reporting sexual assault for women and men: perspectives of college students. Journal of American College Health, 55(3), 15762, doi: 10.3200/JACH.55.3.157-162

Shorey, R. C., Zucosky, H., Brasfield, H., Febres, J., Cornelius, T. L., Sage, C., \& Stuart, G. L. (2012). Dating violence prevention programming: Directions for future interventions. Aggression and Violent Behavior, 17, 289-296. doi: 10.1016/j.avb.2012.03.001

United Nations. (2013). Elimination and prevention of all forms of violence against women and girls. 57th session of the Commission on the Status of Women (CSW57). World Conferences on Women.

Retrieved from http://www.unwomen.org/en/news/in-focus/csw57stop-violence-against-women\#sthash.XM5jd5G7.dpuf

Valls, R., Puigvert, L., Melgar, P., \& García-Yeste, C. (2016). Breaking the silence at the Spanish universities. Findings from the First Study of Violence Against Women on Campuses in Spain. Violence against Women, 22(13), 1-21. doi: 10.1177/1077801215627511

WHO. (2016). Violence against women. Intimate partner and sexual violence against women. Fact sheet, November 2016. Media Centre. World Health Organization. Retrieved from http://www. who.int/mediacentre/factsheets/fs239/en/ 
Ana Vidu is PhD Candidate at the Department of Sociology, University of Barcelona.

Rosa Valls is Professor at the Department of Theory and History of Education, University of Barcelona.

Lidia Puigvert is Professor at the Department of Sociology, University of Barcelona.

Patricia Melgar is Lecturer at the Department of Pedagogy, University of Girona

Mar Joanpere is PhD Candidate at the Department of Sociology, University of Barcelona

Contact Address: Department of Sociology. Faculty of Economics and Business Diagonal, 690 - 696, 08034, Barcelona.

E-mail: ana.vidu@ub.edu 